TARNOWSKIE STUDIA TEOLOGICZNE 36 (2017) NR 1, S. 119-137

http://dx.doi.org/10.15633/tst.2327

ks. Marcin Bałdyga ${ }^{1}$

KATOLICKI UNIWERSYTET LUBELSKI JANA PAWŁA II

\title{
Rekursy administracyjne w systemie sprawiedliwości administracyjnej w Kościele
}

Misją władzy kościelnej jest świadczenie ludziom pomocy w osiągnięciu zbawienia. Mimo iż władza ta pochodzi z ustanowienia Bożego, to jednak nie jest doskonała. Wynika to $\mathrm{z}$ faktu, że funkcje organów władzy pełnią ludzie, którzy pomimo odpowiednich kwalifikacji popełniają błędy. Może to skutkować pojawieniem się napięć w życiu wspólnoty kościelnej. Stąd też $\mathrm{w}$ administracji kościelnej funkcjonuje odpowiedni system kontroli. Może to być kontrola zewnętrzna, czyli uruchamiana przez poszczególne jednostki poprzez wniesienie środków odwoławczych od decyzji wydanych przez organy niższego stopnia do organów hierarchicznie wyższych lub też organów władzy sądowniczej bądź kontrola wewnętrzna - sprawowana z inicjatywy własnej organów władzy kościelnej wyższego rzędu².

Celem niniejszego opracowania jest wskazanie zasad i środków prawnych służących kontroli aktów administracyjnych, wydanych przez organy władzy administracyjnej Kościoła.

\section{Sprawiedliwość administracyjna w Kościele}

W Konstytucji dogmatycznej o Kościele Lumen gentium Soboru Watykańskiego II, odnajdujemy definicję Kościoła, który rozumiany jest jako communio, czyli wspólnota, a Jezus Chrystus, założyciel Kościoła, w którym nieustannie działa Duch Święty, stanowi w nim fundament władzy. Stąd też wynika uprawnienie wiernego, będącego członkiem Kościoła,

\footnotetext{
Marcin Bałdyga - prezbiter archidiecezji warmińskiej. Magister teologii, magister prawa, magister licencjat prawa kanonicznego. Doktorant w Katedrze Prawa Katolickich Kościołów Wschodnich KUL.

2 Por. J. Krukowski, Prawo administracyjne w Kościele, Warszawa 2011, s. 483.
} 
do dochodzenia naprawienia sytuacji, która spowodowała złamanie elementu wspólnotowości poprzez niegodziwe bądź nielegalne działanie kościelnej władzy administracyjnej ${ }^{3}$.

Chcąc sformułować definicję sprawiedliwości administracyjnej, należałoby powiedzieć, że jest to całokształt środków prawnych, dzięki którym wierni mogą żądać od osób sprawujących władzę administracyjną w Kościele zachowania zgodnego ze sprawiedliwością i prawem. Wynika to z podstawowego prawa do obrony, przysługującego wszystkim wiernym na mocy danej pozycji w Kościele, a także przyrodzonej godności.

W obszarze powszechnego nauczania Kościoła, odnoszącego się do ochrony naturalnej godności ludzkiej, znajduje się także system prawa kanonicznego, ukierunkowany na zapewnienie ochrony uniwersalnych praw każdego człowieka, które nie mogą być ani zbyte, ani naruszone. Stąd też warto zaznaczyć, że spojrzenie prawodawcy kościelnego odznacza się większym zasięgiem niż w systemie prawa państwowego. Wynika to z tego, że prawodawca kościelny postawił sobie za cel ochronę podstawowych praw człowieka nie tylko w wymiarze czysto ziemskim, lecz i transcendentnym, czyli wiecznym, mając na uwadze zbawienie dusz. Ochrona praw jednostki ma zasięg wspólnotowy. Otóż prawo kościelne ma za zadanie wychowywać wiernych, zarówno pojedyncze osoby, jak i różne wspólnoty, co idzie $\mathrm{w}$ parze $\mathrm{z}$ zamiarem ukształtowania świata harmonijnego oraz $\mathrm{z}$ integracją osobowości ludzko-chrześcijańskiej, zarówno w aspekcie wspólnotowym, jak i indywidualnym ${ }^{4}$.

Procedura administracyjna, dzięki której można rozwiązać spór powstały między adresatem aktu administracyjnego a jego autorem i jednocześnie powrócić do istniejącego wcześniej ładu, zburzonego poprzez konkretny akt władzy kościelnej, stanowi właśnie przedmiot sprawiedliwości administracyjnej. Warto w tym miejscu wskazać składowe przedmiotu sprawiedliwości administracyjnej. Są nimi: spór administracyjny; środki prawne przysługujące adresatowi aktu administracyjnego w celu dochodzenia

3 Por. F. Lempa, Odpowiedzialność administracji kościelnej za szkody wynikłe z nielegalnego aktu administracyjnego, Lublin 1985, s. 73; Sobór Watykański II, Konstytucja dogmatyczna o Kościele Lumen gentium, w: Sobór Watykański II, Konstytucje, dekrety, deklaracje, Poznań 2002, $\mathrm{nr}$ 14, s. 117.

4 Por. G. Leszczyński, Kościelna procedura administracyjna w Kodeksie Prawa Kanonicznego Jana Pawła II, Warszawa 20o8, s. 43-44. 
swoich uprawnień, właściwy organ władzy - władny daną sprawę rozpatrzeć i załatwić oraz procedura5.

Obowiązujący obecnie kodeks Jana Pawła II zawiera w sobie dwa rodzaje środków odwoławczych przeciwko aktom administracyjnym. Pierwsze $\mathrm{z}$ nich to środki pojednawcze, mające na celu chronić przed pojawieniem się sporu administracyjnego, do których należą: pomoc mediatorów, rada lub urząd pojednawczy. Drugie, którym poświęcone jest niniejsze opracowanie, mają na celu załatwienie sporu. Do tej grupy należy zaliczyć: rekurs hierarchiczny i rekurs do Drugiej Sekcji Sygnatury Apostolskiej. Te środki odwoławcze pozwalają odwołać się do organu wyższego od organu, który jest autorem danego rozstrzygnięcia, a także do Trybunału Sygnatury Apostolskiej będącego trybunałem sądowym ${ }^{6}$.

\section{Zasada legalności w sprawowaniu władzy administracyjnej w Kościele}

Zasada legalności, mająca swoje zastosowanie w porządku prawnym państw demokratycznych, znalazła swoje miejsce także w systemie społecznej nauki Kościoła. We współczesnych systemach prawa należy ona do fundamentalnych zasad ustroju społeczeństw. Ma związek z godnością ludzką i ochroną przynależnych jej praw. Natomiast respektowanie praw wszystkich członków Kościoła domaga się od wszystkich poddania się przepisom prawa kanonicznego.

Organy władzy kościelnej, w celu realizacji zasady legalności, mają obowiązek spełnienia następujących wytycznych: 1) przestrzegania przepisów prawa kanonicznego; 2) przestrzegania zakresu swoich kompetencji przy stanowieniu aktów administracyjnych; 3) zachowywania przepisów proceduralnych; 4) zabezpieczenia środków służących kontroli prawnej, a w szczególności prawa użycia przez jednostkę administrowaną środków

5 Por. G. Leszczyński, Sprawiedliwość administracyjna $w$ Kościele, w: 25-lecie promulgacji Kodeksu Prawa Kanonicznego. Obowiązywanie i stosowanie w Polsce, red. J. Krukowski, Z. Tracz, Łódź 2009, s. 185.

6 Por. J. Krukowski, Prawo administracyjne w Kościele, s. 508-509; Z. Grocholewski, Posoborowy rozwój sprawiedliwości administracyjnej w Kościele, w: Arcybiskup Zenon Grocholewski. Prefekt Kongregacji do Spraw Wychowania Katolickiego. Doktor honoris causa Katolickiego Uniwersytetu Lubelskiego, red. M. Stasiak, Lublin 2001, s. 62-63. 
odwoławczych, skierowanych przeciwko aktom administracyjnym nielegalnym, a także rozstrzygania bezstronnego.

Kościelne organy władzy wykonawczej mają obowiązek wydawania decyzji oraz stanowienia konkretnych aktów administracyjnych z zachowaniem przepisów prawa kanonicznego, które należy rozumieć jako zespół norm usytułowanych w ustawach i innych aktach prawnych, odpowiednio usystematyzowanych, zarówno pochodzenia czysto ludzkiego, jak i Bożego ${ }^{7}$.

Ustawodawca kodeksowy, chcąc chronić Kościół przed arbitralnością władzy ustawodawczej szczebla niższego od Stolicy Apostolskiej, w kan. 135 $\$ 2$ kodeksu prawa kanonicznego [KPK] postawił dodatkowe trzy wymogi: 1) władza ustawodawcza ma być wykonywana zgodnie z obowiązującym prawem; 2) organ władzy ustawodawczej niższego stopnia od organu najwyższej władzy nie jest władny do ważnego jej delegowania, chyba że zastrzeżono inaczej; 3) niższy rangą ustawodawca nie jest uprawniony do wydawania ustaw niezgodnych $\mathrm{z}$ ustawami ustawodawcy wyższego rangą ${ }^{8}$.

Zachowanie zasady legalności nakłada na organy władzy kościelnej zobowiązanie do działania w granicach wyznaczonych przez obowiązujące prawo. Nakłada też obowiązek zachowania czujności, by nie wydawać aktów administracyjnych zakazanych przez system prawa pisanego, jak i zwyczajowego, a także łamiących prawa przysługujące innym.

Działanie kościelnych organów, sprzeczne z powyższymi zasadami, prowadzi do nielegalności działania i skutkuje tym, że również wydany akt administracyjny jest nielegalny ${ }^{9}$.

7 Por. J. Krukowski, Prawo administracyjne w Kościele, s. 344-356; M. Sitarz, Zasada legalności w sprawowaniu władzy administracyjnej w Kościele, w: Organizacja i funkcjonowanie administracji $w$ Kościele, red. J. Krukowski, W. Kraiński, M. Sitarz, Toruń 2011, s. 65, 77-78; F. Przytuła, Zasada legalności a funkcjonowanie administracji kościelnej, Lublin 1985, s. 60; zob. szerzej A. Miziński, Pojęcie kościelnego aktu administracyjnego, w: Organizacja i funkcjonowanie administracji w Kościele, s. 109-142.

8 Por. J. Krukowski, Kanoniczne prawo powszechne i prawo partykularne $w$ Polsce. Konferencja Episkopatu Polski i synody, w: 25-lecie promulgacji Kodeksu Prawa Kanonicznego..., s. $63-65$.

9 Por. M. Sitarz, Kompetencje kontrolne Stolicy Apostolskiej względem działalności legislacyjnej organów władzy w Kościele partykularnym, w: Finis legis Christus. Księga pamiątkowa dedykowana Księdzu Profesorowi Wojciechowi Góralskiemu z okazji siedemdziesiątej rocznicy urodzin, red. J. Wroceński, J. Krajczyński, t. 1, Warszawa 2009, s. 725-737; F. Przytuła, Zasada legalności a funkcjonowanie..., s. 61. 
Wymóg przestrzegania zasady legalności przejawia się także w tym, że wymaga się kontroli zgodności ustaw o zasięgu partykularnym, których autorami są organy niższe od papieża, z ustawami o charakterze powszechnym. Obowiązujący kodeks prawa kanonicznego wymaga kontroli ustaw partykularnych, których autorami są synody partykularne bądź konferencje biskupów, poprzez uzyskanie, jeszcze przed ich promulgacją, rekognicji od Stolicy Apostolskiej ${ }^{10}$.

Działanie kościelnego organu administracji, aby było zgodne z omawianą zasadą, powinno przebiegać nie tylko w obszarze kompetencji danego organu, ale także zgodnie z przepisami prawa materialnego i według odpowiedniej procedury, wskazanej przez prawodawcę. W prawie kanonicznym wyróżniamy administracyjną procedurę ogólną, obowiązującą przy wydawaniu ogółu aktów administracyjnych, a także procedurę szczególną, którą należy uruchomić podczas wydawania aktów administracyjnych konkretnie wskazanych kategorii, jak chociażby procedura przy ekskardynacji i inkardynacji duchownych ${ }^{11}$.

Z zasady legalności wyprowadzono także gwarancję odpowiedniej ochrony prawnej jednostki w dwóch sektorach. Pierwszy traktuje o proklamacji fundamentalnych praw chrześcijan, o której mowa w kan. 208-233 KPK. Drugi odnosi się do ustanowienia środków odwoławczych, dzięki którym każdy chrześcijanin ma prawo odwołania się do organów władzy kościelnej w sytuacji, gdy twierdzi, że jego prawa należne mu w Kościele zostały złamane, czy to przez organ władzy kościelnej, czy przez konkretnego wiernego. Wyraz tego znajdujemy w uprawnieniu jednostki do skorzystania ze środków odwoławczych w wypadku naruszenia jej praw przez konkretny akt administracyjny i w gwarancji, że problem ten zostanie rozwiązany w sposób obiektywny i bezstronny ${ }^{12}$.

W zakresie kontroli aktów administracyjnych przepisy zadanie to rezerwują dla Stolicy Apostolskiej, która jest odpowiedzialna za czuwanie nad

${ }^{10}$ Por. M. Sitarz, Zasada legalności w sprawowaniu..., s. 81.

${ }^{11}$ Zob. szerzej G. Leszczyński, Zasady ogólnej procedury administracyjnej $w$ Kodeksie Prawa Kanonicznego z 1983 roku, w: Organizacja i funkcjonowanie administracji w Kościele, s. $167-178$.

${ }_{12}$ Por. M. Sitarz, Zasada legalności w sprawowaniu..., s. 83-84; zob. szerzej: A. Dzięga, Ochrona sądowa praw wiernych, w: 25-lecie promulgacji Kodeksu Prawa Kanonicznego..., s. 99-106; T. Rozkrut, Ochrona sądowa praw wiernych - szczegółowe zagadnienia wybrane, w: 25-lecie promulgacji Kodeksu Prawa Kanonicznego..., s. 107-120. 
jednością systemu prawa. W art. 156 konstytucji Pastor bonus czytamy: „Papieska Rada Interpretacji Tekstów Prawnych [obecnie: Papieska Rada Tekstów Prawnych] jest do dyspozycji pozostałych dykasterii Kurii Rzymskiej, wspierając je w ten sposób, ażeby wydawane prze nie dekrety wykonawcze oraz instrukcje były zgodne z przepisami obowiązującego prawa i sporządzone w poprawnej formie prawnej" ${ }^{\prime 3}$.

\section{Rekursy administracyjne}

Rekursy administracyjne mogą występować w trzech formach. Należą do nich: rekurs, definiowany jako prośba skierowana do autora danego aktu administracyjnego o jego odwołanie bądź poprawienie, rekurs hierarchiczny, a także rekurs bezpośredni do papieża. Szczegółowe unormowania prawne w omawianej materii zawarte zostały w kan. 1732-1739 KPK z 1983 roku.

\section{Prośba do autora o poprawienie lub odwołanie aktu}

Ta forma przeciwdziałania powstawaniu sporu swój fundament posiada już w początkowych czasach istnienia Kościoła. Wcześniej prośba do autora aktu administracyjnego o odwołanie lub poprawienie go miała postać suplikacji, zwanej rekursem łaski. Cechą charakterystyczną tej instytucji jest to, że kieruje się ją do autora aktu administracyjnego.

Warto podkreślić, że prośba do autora aktu o poprawienie lub odwołanie konkretnego aktu administracyjnego skupia się głównie na organie, który władny jest udzielić przywileju polegającego na poprawieniu lub odwołaniu aktu, a nie na odbiorcy aktu. Stąd też nie można go definiować jako rekursu w ścisłym rozumieniu - różni się on bowiem od rekursu tym, że występuje tu tożsamość podmiotów: ad quem i a quo ${ }^{14}$.

Prośba o poprawienie bądź odwołanie aktu administracyjnego winna być wystosowana wyłącznie pisemnie, o czym mowa w treści kan. $1734 \$ 1$ obecnego kodeksu. Nie określono żadnych szczególnych wymogów, nie ma nawet obowiązku podania motywów prośby. Z pisma musi jednak jasno wynikać,

${ }^{13}$ Ioannes Paulus II, Constitutio apostolica Pastor bonus, 28.06.1988, „Acta Apostolicae Sedis" [dalej: AAs] 80 (1988), s. 841-912; tekst polski w: Ustrój hierarchiczny Kościoła, red. W. Kacprzyk, M. Sitarz, Lublin 2006, s. 252.

${ }^{14}$ Por. G. Leszczyński, Kościelna procedura..., s. 69-70. 
kto jest autorem prośby i o co prosi. Złożenie omawianej prośby skutkuje zawieszeniem aktu administracyjnego, którego ona dotyczy.

Skierowanie prośby do autora danego aktu administracyjnego jest obligatoryjne. Bezpośrednie złożenie rekursu hierarchicznego, z pominięciem wskazanej prośby, skutkowałoby niemożnością przyjęcia go przez organ, do którego rekurs byłby skierowany.

Natomiast przyjęcie rekursu sprawiłoby nieważność późniejszego rozstrzygnięcia. Ma to swoje źródło w treści kan. $1734 \$ 1$, gdzie występuje zwrot debet, rozumiany jako brak uprawnienia do złożenia rekursu, gdy odbiorca aktu administracyjnego uprzednio nie wystosował pisemnej prośby do autora aktu o jego poprawienie bądź odwołanie. Poparcie powyższego twierdzenia odnajdujemy w kan. $1734 \$ 2$, w którym prawodawca wskazuje konkretny termin na złożenie prośby.

Na złożenie charakteryzowanej prośby, zgodnie z treścią kan. $1734 \$ 2$, odbiorca aktu administracyjnego ma termin zawity dziesięciu dni użytecznych od chwili zawiadomienia o danym akcie administracyjnym. Jeżeli adresat dekretu nie uczyni tego we wskazanym terminie, z powodu niedbalstwa bądź innych przyczyn, to traci prawo do wniesienia prośby do autora aktu. Traci też prawo złożenia rekursu hierarchicznego, a gdyby to uczynił, rekursu nie należy przyjąć. Wskazany termin ma również zastosowanie przy aktach, których autorami są dykasterie Kurii Rzymskiej ${ }^{15}$.

Prawodawca w kan. $1734 \$ 3$ wskazuje pewne wyjątki od reguły obligatoryjnego wniesienia prośby do autora aktu administracyjnego o jego poprawienie lub odwołanie. Mowa tu chociażby o rekursie złożonym na ręce biskupa przeciw aktom, których autorami są władze mu podlegające, a także w odniesieniu do rekursu skierowanego przeciwko dekretowi, który stanowi właśnie o rekursie hierarchicznym pod warunkiem, że decyzja nie została wydana bezpośrednio przez biskupa. Kolejnym wyjątkiem są rekursy powstałe na mocy kan. 57 i 1735. Stąd też nie jest obligatoryjne wniesienie omawianej prośby, gdy autorem dekretu są władze bezpośrednio podlegające biskupowi diecezjalnemu, np. wikariusze: biskupi lub generalny. Obowiązek pojawia się dopiero, gdy rozstrzygnięcie w sprawie poprzedniego rekursu zostało podjęte przez samego biskupa. Obowiązek nie pojawia się również

${ }^{15}$ Por. T. Białobrzeski, Wady kościelnych aktów administracyjnych, w: Organizacja i funkcjonowanie administracji w Kościele, s. 195; G. Leszczyński, Sprawiedliwość administracyjna..., s. $190-191$. 
wtedy, gdy rekurs zostaje skierowany przeciw domniemanej odpowiedzi negatywnej ze strony obowiązanej do sporządzenia aktu administracyjnego ustawą lub w oparciu o prośbę, o której mowa w treści kan. 1734. Trzeba w tym miejscu zaakcentować, że pomimo braku w tej sytuacji zobowiązania do obligatoryjności złożenia prośby, nie wiąże się to z zakazem prawnym, choć w tego typu sytuacjach nie wystąpi skutek zawieszający wykonanie dekretu ${ }^{16}$.

Warto podkreślić, że prośba o poprawienie lub odwołanie aktu administracyjnego skierowana do jego autora nie jest typową prośbą o łaskę, gdyż obliguje ona autora danego aktu do powtórnego odniesienia się do całości sprawy. Zgodnie z treścią kan. $1736 \$ 1$ skierowanie do autora dekretu powyższej prośby wywołuje skutek w postaci zawieszenia jego wykonania w sprawach, w których podobny skutek wiąże się z wniesieniem rekursu hierarchicznego. Trzeba zaznaczyć również, że rekurs hierarchiczny powoduje zawieszenie wykonania aktu administracyjnego jedynie w konkretnych sytuacjach, wskazanych przez prawodawcę, np. rekurs odnoszący się do dekretu, na mocy którego nastąpiłoby przeniesienie proboszcza parafii.

W pozostałych przypadkach, w których prośba do autora aktu administracyjnego nie wywołuje powyższego skutku, jeśli zainteresowany adresat prośby nie będzie wnosił o zawieszenie wykonania go w terminie dziesięciu dni od dnia otrzymania prośby, wtedy autor prośby uprawniony jest, by prosić o to wyższego przełożonego. Ten natomiast może zawiesić wykonanie aktu administracyjnego, gdy wystąpi poważna przyczyna i mając na uwadze zbawienie dusz. Taka procedura zawieszenia wykonania aktu administracyjnego w sytuacji, gdy następnie zostaje wniesiony rekurs, upoważnia osobę kompetentną do załatwienia sprawy, by podjęła decyzję dotyczącą potwierdzenia bądź odwołania zawieszenia. Gdy minął wskazany przez prawodawcę termin upoważniający adresata dekretu do wniesienia rekursu, wtedy ustaje skutek zawieszający wykonania dekretu ${ }^{17}$.

Przepisy prawa kanonicznego wskazują termin trzydziestodniowy na rozpatrzenie prośby do autora aktu o jego poprawienie bądź odwołanie. Autor dekretu może różnie potraktować wniesioną do niego prośbę. Jest władny,

${ }^{16}$ Por. W. Kraiński, Kontrola kościelnych aktów administracyjnych pod względem legalności i poprawności merytorycznej, w: Organizacja i funkcjonowanie administracji w Kościele, s. 207; J. Krukowski, Prawo administracyjne w Kościele, s. 514.

${ }_{17}$ Por. G. Leszczyński, Kościelna procedura..., s. 73-74. 
by ją zignorować, odrzucić lub przyjąć i poprawić bądź odwołać wydany uprzednio akt administracyjny. W momencie, gdy odwołuje dany dekret, wygasają podstawy uruchamiania drogi rekursu hierarchicznego. W tej sytuacji autor prośby osiągnął założony przez siebie cel, którym jest odwołanie niesprawiedliwego aktu. Natomiast w sytuacji jedynie poprawienia go lub potwierdzenia wydanego dekretu adresatowi przysługuje prawo złożenia rekursu hierarchicznego. Przedmiotem rekursu będzie wyjściowy akt administracyjny, gdy zapadnie decyzja potwierdzająca akt administracyjny, natomiast w sytuacji poprawienia pierwotnego będzie nim nowy akt administracyjny.

Prawodawca w treści kan. 1735 stanowi, że w sytuacji, gdy w ciągu trzydziestu dni od dnia, w którym do autora aktu administracyjnego dotarła prośba odbiorcy aktu, poinformuje on o wydaniu nowego dekretu, którym poprawił on dekret pierwotny bądź prośbę odrzucił, to wtedy rozpoczyna swój bieg termin do złożenia rekursu, licząc od dnia otrzymania nowego dekretu przez adresata aktu. W sytuacji, gdy autor aktu nie wydał żadnej decyzji w ciągu trzydziestu dni, czas na wniesienie rekursu biegnie, poczynając od trzydziestego dnia. Wynika stąd reguła, że prawodawca traktuje milczenie autora aktu jako wydanie negatywnego aktu administracyjnego. Trzeba podkreślić, że wskazanie terminu trzydziestu dni, odnoszącego się do milczenia autora aktu administracyjnego, stanowi swoisty wyjątek od terminu, o którym mowa w kan. 57, wynoszącym trzy miesiące, po upływie którego powstaje domniemanie wydania odpowiedzi negatywnej. Należy pamiętać, że w kan. $57 \$ 1$ prawodawca wskazuje na sposobność wyznaczenia innego terminu, pod warunkiem że dopuszcza taką możliwość przepis ustawy ${ }^{18}$.

\section{Rekurs hierarchiczny}

Rekursem hierarchicznym jest rekurs administracyjny, skierowany do organu administracyjnego wyższego stopnia w stosunku do tego organu, który jest autorem zaskarżanego aktu. Każdy, kto uważa siebie za pokrzywdzonego dekretem, zgodnie z treścią kan. $1737 \$ 1$, ma prawo wnieść rekurs do przełożonego hierarchicznego tego, kto dekret wydał.

Za podmiot czynny rekursu uznawana jest ta osoba, która twierdzi, że jest dekretem pokrzywdzona. Zgodnie z obowiązującym prawem władna

${ }^{18}$ Por. G. Erlebach, A. Dzięga, J. Krukowski (red. nauk.), R. Sztychmiler, Komentarz do Kodeksu Prawa Kanonicznego, t. 5: Księga VII. Procesy, Poznań 2007, s. 427-428. 
do wniesienia rekursu jest jednakże osoba posiadająca ogólną zdolność do czynności prawnych w Kościele oraz właściwą legitymację odnoszącą się zarówno do motywu, jak i przedmiotu rekursu.

W Kościele posiadaniem ogólnej zdolności prawnej odznaczają się osoby prawne i fizyczne. Warto zaznaczyć, że także osoba nieochrzczona może złożyć rekurs. Natomiast do tego, by jakaś grupa osób należących do wspólnoty Kościoła posiadała prawo wniesienia rekursu, musi spełniać warunek odznaczania się osobowością prawną, publiczną bądź prywatną. Wynika stąd, że stowarzyszenia i grupy niemające osobowości prawnej nie posiadają takiego uprawnienia. Ograniczenie to jednakże nie wynika wprost $\mathrm{z}$ treści kan. 310, lecz z negatywnej odpowiedzi Papieskiej Komisji ds. Autentycznej Interpretacji KPK, udzielonej 20 czerwca 1987 roku grupie osób, która nie miała osobowości prawnej w Kościele, na pytanie odnoszące się do możności skierowania przez nich jako grupy rekursu hierarchicznego skierowanego przeciw decyzji biskupa diecezjalnego, pod władzą którego byli.

Trzeba też podkreślić, że odpowiedź Papieskiej Komisji Interpretacyjnej, mimo że była jednoznaczna w stosunku do stowarzyszeń niemających osobowości prawnej, to w odniesieniu do stowarzyszeń, które nie miały osobowości prawnej, a charakteryzowały się posiadaniem statutów zatwierdzonych przez właściwą władzę, już taka nie jest.

Legitymacja do wniesienia rekursu hierarchicznego przysługuje osobie będącej w polu oddziaływania dekretu i twierdzącej, że jest on przyczyną pogorszenia jej sytuacji w Kościele, narusza jej prawa, pozbawia dóbr, z których korzystała. Istotne jest to, że nie jest wymagana pewność absolutna pogorszenia jej sytuacji, ale tylko przeświadczenie, że wydany akt administracyjny powoduje takie właśnie skutki. Prawodawca w kan. $1737 \$ 1$ zastosował zwrot contendit, a więc osoba, która uważa się za pokrzywdzoną, uprawniona jest do wniesienia rekursu niezależnie od tego, czy to przekonanie znajdzie swoje potwierdzenie w rozstrzygnięciu organu hierarchicznego. Trzeba zaakcentować również, że rekurs może wnieść osoba, która uważa, że jest pokrzywdzona dekretem osobiście i aktualnie. Interes osobisty należy traktować jako interes danej osoby, a nie osób trzecich, natomiast aktualny jako odnoszący się do naruszenia prawa nie w przeszłości bądź przyszłości, ale trwającego aktualnie ${ }^{19}$.

19 Por. J. Krukowski, Prawo administracyjne w Kościele, s. 521-524; G. Leszczyński, Sprawiedliwość administracyjna..., s. 192-193. 
Bezproblematyczny jest natomiast temat podmiotu biernego rekursu hierarchicznego. Jest nim organ będący autorem zaskarżonego aktu administracyjnego. Należy podkreślić, że do tego grona nie może należeć ani papież, ani sobór powszechny. Mowa o tym w treści kan. 1732, gdzie prawodawca stanowi, że przeciw aktom wydanym przez najwyższą władzę kościelną nie jest możliwe składanie rekursów. Również nie jest dopuszczalne składanie rekursów od aktów, których autorami są dykasterie Kurii Rzymskiej, gdyż w tym przypadku istnieje możliwość złożenia wyłącznie rekursu sądowego do Drugiej Sekcji Sygnatury Apostolskiej.

Zgodnie z treścią kan. $1734 \$ 1$ organem hierarchicznym pierwszego stopnia jest biskup diecezjalny w obszarze działania organów mu podległych. Warto podkreślić, że na równi z biskupem diecezjalnym należy traktować osoby, o których mowa w kan. 368, 381 oraz 295. Natomiast od rozstrzygnięcia wydanego przez biskupa diecezjalnego można wnieść rekurs hierarchiczny do odpowiedniej dykasterii Kurii Rzymskiej, a więc organu wyższego hierarchicznie. Mowa o tym w art. $19 \$ 1$ konstytucji Pastor bonus Jana Pawła II: „Rekursy hierarchiczne przyjmuje dykasteria, kompetentna $\mathrm{z}$ racji przedmiotu sprawy, z zachowaniem przepisu art. $21 \$ 1$ ”. Natomiast $\mathrm{w}$ art. $21 \$ 1$ wspomnianej konstytucji czytamy: „Sprawy, które wchodzą w zakres kompetencji kilku dykasterii, powinny być wspólnie przebadane przez zainteresowane dykasterie. Przełożony dykasterii, która zaczęła załatwiać sprawę, zwołuje zebranie, czy to z urzędu, czy na prośbę innej zainteresowanej dykasterii. Jeśli jednak wymaga tego materia przedstawionej sprawy, należy ją przedstawić na sesji plenarnej zainteresowanych dykasterii. Zebraniu przewodniczy przełożony dykasterii, która je zwoła, lub jej sekretarz, gdy zbierają się sami tylko sekretarze"20.

Podłożem rekursu jest wada aktu administracyjnego. Może on zostać uruchomiony z jakiejkolwiek słusznej przyczyny. Zastosowanie, w treści kan. $1737 \$ 1$, zwrotu quodlibet wskazuje na szerokie rozumienie motywu rekursu i wyjście poza sferę legalności. Formalny motyw, odnoszący się do nielegalności danego aktu administracyjnego, ma swoje źródło w naruszeniu normy prawnej naturalnej bądź pozytywnej czy zwyczajowej i może obejmować każdy element biorący udział w powstaniu aktu, czyli przedmiot, formę, cel, przyczyny, podmiot albo inny jeszcze czynnik niezbędnego

${ }^{20}$ Por. Ioannes Paulus II, Constitutio apostolica Pastor bonus..., s. 194; G. Leszczyński, Sprawiedliwość administracyjna..., s. 193. 
do ważności kościelnego aktu administracyjnego. Jakkolwiek samo ukazanie przyczyn nielegalności konkretnego aktu administracyjnego nie stanowi wielkiego problemu, to określenie przesłanek, z których wynikałoby, że konkretny akt administracyjny może zostać uznany za niestosowny lub nieużyteczny, jest trudniejsze. Kluczowe jest, by nieużyteczność aktu czy jego niestosowność mieściły się w obszarze stricte legalnego tłumaczenia motywu' ${ }^{21}$.

Przez podmiotowy motyw rekursu należy rozumieć określoną prośbę spisaną przez jego autora, czyli to, o co będzie prosił autor rekursu. Autor rekursu może wnioskować, aby przełożony uznał dany akt administracyjny za nieważny, odwołał, uchylił lub zastąpił drugim, unieważnił lub poprawił.

Przedmiotem rekursu hierarchicznego, zgodnie ze wskazaniami zawartymi w kan. 1732, mogą być wydane w obszarze zewnętrznym pozasądowym dekrety i pozostałe akty administracyjne $\mathrm{z}$ wyłączeniem tych, których autorami są papież i sobór powszechny.

Procedura rozpatrzenia rekursu hierarchicznego składa się z trzech zasadniczych faz. Pierwszą jest złożenie rekursu, drugą etap dowodowy, a trzecią rozstrzygnięcie organu hierarchicznego. Decyzja ostateczna, która rozstrzyga rekurs hierarchiczny, zobowiązuje zainteresowane strony do podporządkowania się jej. W sytuacji, gdyby podmiot czynny bądź bierny czuł się pokrzywdzony ostatecznym rozstrzygnięciem rekursu, autorem którego jest konkretna kongregacja Roty Rzymskiej, ma prawo skierować rekurs do Drugiej Sekcji Sygnatury Apostolskiej albo prosić biskupa Rzymu o łaskę beneficjum novae audientiae ${ }^{22}$.

\section{Rekurs sądowo-administracyjny}

Chcąc przeanalizować ewolucję instytucji rekursu sądowo-administracyjnego, należałoby wpierw przywołać treść art. 106 konstytucji Regimini Ecclesiae Universae, w którym mowa o tym że, Druga Sekcja Sygnatury Apostolskiej zajmuje się rozstrzyganiem sporów wynikłych z kościelnego aktu administracyjnego, wniesionych do niej poprzez rekurs przeciw decyzji

${ }^{21}$ Por. G. Leszczyński, Kościelna procedura..., s. 84-85; T. Białobrzeski, Wady kościelnych aktów..., s. 195-196.

${ }^{22}$ Por. J. Krukowski, Prawo administracyjne w Kościele, s. 525, 535-536. 
odpowiedniej dykasterii Kurii Rzymskiej, w każdym przypadku, gdy twierdzi się, że sam akt narusza czyjeś uprawnienia ${ }^{23}$.

Wymogi odnoszące się do osoby, która chce wnieść rekurs do trybunału Drugiej Sekcji Sygnatury Apostolskiej, są następujące: osoba ta winna odznaczać się zdolnością procesową, a także specjalną legitymacją do wzięcia udziału w procesie. Mamy więc kilka przypadków podmiotu czynnego omawianego rekursu. Należy wymienić chociażby: adresata aktu administracyjnego autorstwa biskupa bądź niższego przełożonego, od którego został złożony rekurs hierarchiczny do dykasterii rzymskiej i rozstrzygnięciem tejże dykasterii zaskarżony akt został potwierdzony; adresata aktu administracyjnego, który został wydany przez którąś z dykasterii rzymskich oraz adresata aktu administracyjnego, który przez dykasterię rzymską został zastąpiony nowym aktem administracyjnym bądź został zmieniony.

Warto postawić pytanie, czy czynny interes wniesienia rekursu przysługuje tylko stronie, która jest pokrzywdzona kościelnym aktem administracyjnym czy może także jednostce administracyjnej niższego stopnia w sytuacji przyjęcia rekursu hierarchicznego, skierowanego przeciwko jej rozstrzygnięciu i tym samym odwołaniu bądź zmienieniu wydanej przez nią decyzji. Orzecznictwo przewiduje uprawnienie niższej jednostki administracyjnej do wniesienia rekursu do Drugiej Sekcji Sygnatury Apostolskiej, by nie stawiać jej w gorszym położeniu od osoby prywatnej. Należy pamiętać, że w procedurze sądowo-administracyjnej chodzi o stwierdzenie legalności bądź nielegalności konkretnego dekretu, stąd też autor aktu administracyjnego, który w drodze rekursu został poprawiony lub oddalony, może w sytuacji, gdy twierdzi, iż wydany przez niego akt administracyjny jest słuszny i wydany legalnie, domagać się udowodnienia legalności swojego procedowania $^{24}$.

Szukając potwierdzenia, że w studiowanym wypadku bierną stroną rekursu jest niższy organ administracyjny, przywoływano wpierw treść art. 106 konstytucji Regimini Ecclesiae Universae, w którym odnajdujemy stwierdzenie, że przez przedmiot rekursu należy rozumieć akt administracyjny

${ }_{23}$ Por. Paulus vi, Constitutio apostolica De Romana Curia Regimini Ecclesiae Universae, 15.08.1967, AAS 59 (1967), s. 885-928; tekst polski w: Ustrój hierarchiczny Kościoła, s. 191.

${ }^{24}$ Por. A. Miziński, Rekurs do Najwyższego Trybunału Sygnatury Apostolskiej z tytułu nielegalności aktu administracyjnego, „TEKA Komisji Prawniczej PAN Oddział w Lublinie” 4 (2011), s. $103-105$. 
władzy niższej. Podobne twierdzenie odnajdujemy w deklaracji Sygnatury Apostolskiej z 9 listopada 1970 roku².

Natomiast przedstawicielami przeciwnej opinii w badanej kwestii byli Piero A. Bonet i Eduardo Labandeira twierdzący, że wyłącznie dykasteria rzymska może być traktowana jako bierny podmiot rekursu, gdyż to właśnie jej akt, którym potwierdziła akt niższego rzędu kościelnego organu administracyjnego, jest przedmiotem rekursu wnoszonego do Drugiej Sekcji Sygnatury Apostolskiej.

Warto podkreślić, że niektórzy autorzy prezentują pogląd, iż do grona podmiotów biernych rekursu trzeba zaliczyć niższą jednostkę administracyjną, będącą autorem zaskarżonego aktu, oraz właściwą dykasterię, która potwierdziła tenże akt administracyjny. Należy stwierdzić, że orzecznictwo potwierdzało to ostatnie twierdzenie, które znajduje swoje odzwierciedlenie w art. 123 obowiązującej konstytucji Pastor bonus: „\$1. Sygnatura rozpatruje rekursy [...] przeciwko pojedynczym aktom administracyjnym, wydanym lub potwierdzonym przez dykasterie Kurii Rzymskiej, gdy chodzi o stwierdzenie, czy zaskarżony akt naruszył jakąś ustawę w samym rozstrzygnięciu lub procedurze. $\$ 2$. Jeśli wnoszący rekurs tego się domaga, w powyższych wypadkach Sygnatura obok orzeczenia i niezgodności z prawem może rozpatrzyć także sprawę naprawienia szkód wyrządzonych nielegalnym aktem. $\$ 3$. Sygnatura rozpatruje także inne spory administracyjne, przekazane jej przez papieża lub dykasterie Kurii Rzymskiej, jak również konflikty kompetencyjne między dykasteriami” ${ }^{26}$.

Jednym z kluczowych problemów odnoszących się do procesu sądowo-administracyjnego było wskazanie przyczyny rekursu zarówno formalnego, jak i podmiotowego, mogącego być przyczyną sprawczą wniesienia go do Drugiej Sekcji Sygnatury Apostolskiej. Warto przypomnieć, że prawodawca, w art. 106 konstytucji apostolskiej Regimini Ecclesiae Universae, wskazywał naruszenie czyjegoś prawa (violatio legis) jako formalny przedmiot rekursu. Problem ten został również zbadany przez Papieską Komisję ds. Interpretacji Dekretów Soboru Watykańskiego II, która sprecyzowała, że violatio legis należy definiować jako błąd prawny popełniony w przepisanym prawem postępowaniu lub w zarządzeniu, które musi zostać wydane. Należy

${ }_{25}$ Por. Paulus vi, Constitutio apostolica De Romana Curia..., s. 191.

${ }^{26}$ Por. G. Leszczyński, Sprawiedliwość administracyjna..., s. 197-198; Ioannes Paulus II, Constitutio apostolica Pastor bonus..., s. 246-247. 
zaznaczyć, iż Komisja zastąpiła termin violatio legis zwrotem error iuris, czyli błąd prawny ${ }^{27}$.

W kan. $1400 \$ 2$ obowiązującego kodeksu prawa kanonicznego czytamy: „Natomiast spory powstałe na skutek wydania aktu władzy administracyjnej mogą być wniesione tylko do przełożonego albo do trybunału administracyjnego". Wynika stąd, że prawodawca kodeksowy nie zawęża kompetencji Sygnatury Apostolskiej tylko do badania aktów administracyjnych pod względem ich legalności, lecz daje większe uprawnienia, o czym mowa chociażby w kan. $1445 \$ 2$ : „Tenże trybunał rozpatruje spory powstałe na skutek działania kościelnej władzy administracyjnej, przekazane do niej zgodnie $\mathrm{z}$ przepisami prawa i inne spory administracyjne, przekazane mu przez Biskupa Rzymskiego lub dykasterie Kurii Rzymskiej i konflikty właściwości między tymi dykasteriami”.

Materia, która zgodnie z treścią kanonów była tylko ogólnym stwierdzeniem, została uszczegółowiona w treści zacytowanego wcześniej art. 123 Pastor bonus Jana Pawła II oraz art. $34 \$ 1-2$ Lex propria Supremi Tribunalis Signaturae Apostolicae Benedykta xvi [dalej: Lex propria]. Dzięki temu dopuszczalne jest skierowanie do Trybunału Sygnatury Apostolskiej prośby mającej na celu nie tylko uchylenie konkretnego aktu administracyjnego czy jego modyfikację, ale i naprawienie wynikłych z tego aktu szkód. Warunkiem przyjęcia rekursu wg art. $74 \$ 1$ Lex propria jest wniesienie go w terminie 60 dni użytecznych.

Swoistą nowością wprowadzoną przez Lex propria jest możliwość odrzucenia rekursu na samym wstępie, na mocy dekretu sekretarza Sygnatury, po wysłuchaniu promotora sprawiedliwości. Może to nastąpić tylko w sytuacji, gdy rekurs w sposób oczywisty jest pozbawiony podstawy merytorycznej. Strona czująca się pokrzywdzona tą decyzją ma prawo odwołać się do Kongresu Drugiej Sekcji Sygnatury Apostolskiej w terminie zawitym 10 dni użytecznych. Negatywna decyzja kongresu nie może zostać zaskarżona $^{28}$.

Skutki prawne ostatecznej decyzji wydanej przez Drugą Sekcję Sygnatury Apostolskiej rozciągają się na strony procesu. Jeśli rekurs uznano za pozbawiony przyczyny, następuje uznanie zaskarżonego aktu za zgodny z prawem, co nie oznacza jego potwierdzenia, gdyż Sygnatura wydaje osąd tylko

${ }^{27}$ Por. T. Białobrzeski, Wady kościelnych aktów..., s. 196-197.

${ }^{28}$ Por. A. Miziński, Rekurs do Najwyższego Trybunału..., s. 106, 112. 
w obszarze przedmiotu postępowania. Oznacza to, że decyzja potwierdzająca legalność kościelnego aktu administracyjnego jest tylko tytułem uprawniającym do jego wykonania.

Natomiast w sytuacji, gdy rekurs badany w Drugiej Sekcji Sygnatury Apostolskiej zakończy się rozstrzygnięciem kwalifikującym zaskarżony akt administracyjny jako nielegalny, to zostanie on w całości bądź części anulowany. Orzeczenie Sygnatury Apostolskiej wywołuje skutki ex tunc.

Decyzja wydana przez Drugą Sekcję Sygnatury Apostolskiej, stwierdzająca, że zaskarżony akt jest nielegalny, jednocześnie zobowiązuje organ kościelnej władzy administracyjnej, będący jego autorem, do dostosowania zarówno sytuacji faktycznej, jak i prawnej do dyspozycji decyzji. Jeśli zaskarżony akt administracyjny anulowano w całości, pojawia się obowiązek wydania nowego aktu, natomiast $\mathrm{w}$ momencie częściowego anulowania organ administracyjny może, zgodnie z rozstrzygnięciem Drugiej Sekcji, zmodyfikować go w części. W sytuacji, gdyby odmowa wydania kościelnego aktu administracyjnego była przedmiotem rekursu, na organ administracyjny może zostać nałożony obowiązek wydania takiego aktu ${ }^{29}$.

\section{Zakończenie}

Funkcjonująca w Kościele zasada legalności zobowiązuje organy administracji kościelnej do przestrzegania: norm prawnych, zakresu swoich kompetencji w stanowieniu aktów administracyjnych, zachowywania przepisów proceduralnych, a także zabezpieczenia środków służących kontroli prawnej, a w szczególności prawa użycia przez jednostkę administrowaną środków odwoławczych, skierowanych przeciwko aktom administracyjnym nielegalnym, a także rozstrzygania bezstronnego.

W systemie kościelnego prawa administracyjnego wierni mają szeroki wachlarz środków prawnych, służących ochronie należnych im praw podmiotowych: od środków pojednawczych, których celem jest podjęcie działań zmierzających do uniknięcia sporu administracyjnego, po środki odwoławcze, umożliwiające dochodzenie własnych praw na sali sądowej czy forum administracyjnym.

${ }^{29}$ Por. G. Leszczyński, Sprawiedliwość administracyjna..., s. 200-201. 


\section{Bibliografia}

Białobrzeski T., Wady kościelnych aktów administracyjnych, w: Organizacja i funkcjonowanie administracji w Kościele, red. J. Krukowski, W. Kraiński, M. Sitarz, Toruń 2011, s. 179-200.

Codex Iuris Canonici auctoritate Ioannis Pauli PP. II promulgatus. Kodeks prawa kanonicznego. Przekład polski zatwierdzony przez Konferencję Episkopatu, Poznań 1984.

Dzięga A., Ochrona sądowa praw wiernych, w: 25-lecie promulgacji Kodeksu Prawa Kanonicznego. Obowiązywanie i stosowanie w Polsce, red. J. Krukowski, Z. Tracz, Łódź 2009, s. 99-106.

Erlebach G., Dzięga A., Krukowski J. (red. nauk.), Sztychmiler R., Komentarz do Kodeksu Prawa Kanonicznego, t. 5: Księga VII. Procesy, Poznań 2007.

Grocholewski Z., Posoborowy rozwój sprawiedliwości administracyjnej w Kościele, w: Arcybiskup Zenon Grocholewski. Prefekt Kongregacji do Spraw Wychowania Katolickiego. Doktor honoris causa Katolickiego Uniwersytetu Lubelskiego, red. M. Stasiak, Lublin 2001, s. 57-72.

Ioannes Paulus II, Constitutio apostolica Pastor bonus, 28.06.1988, „Acta Apostolicae Sedis" 8o (1988), s. 841-912; tekst polski w: Ustrój hierarchiczny Kościoła, red. W. Kacprzyk, M. Sitarz, Lublin 2006, s. 217-257.

Kraiński W., Kontrola kościelnych aktów administracyjnych pod względem legalności i poprawności merytorycznej, w: Organizacja i funkcjonowanie administracji w Kościele, red. J. Krukowski, W. Kraiński, M. Sitarz, Toruń 2011, s. 201215.

Krukowski J., Kanoniczne prawo powszechne i prawo partykularne w Polsce. Konferencja Episkopatu Polski i synody, w: 25-lecie promulgacji Kodeksu Prawa Kanonicznego. Obowiązywanie i stosowanie w Polsce, red. J. Krukowski, Z. Tracz, Łódź 2009, s. 60-68.

Krukowski J., Prawo administracyjne w Kościele, Warszawa 2011.

Lempa F., Odpowiedzialność administracji kościelnej za szkody wynikłe z nielegalnego aktu administracyjnego, Lublin 1985.

Leszczyński G., Kościelna procedura administracyjna w Kodeksie Prawa Kanonicznego Jana Pawła II, Warszawa 2008.

Leszczyński G., Sprawiedliwość administracyjna w Kościele, w: 25-lecie promulgacji Kodeksu Prawa Kanonicznego. Obowiązywanie i stosowanie w Polsce, red. J. Krukowski, Z. Tracz, Łódź 2009, s. 185-202. 
Leszczyński G., Zasady ogólnej procedury administracyjnej w Kodeksie Prawa Kanonicznego $z 1983$ roku, w: Organizacja i funkcjonowanie administracji w Kościele, red. J. Krukowski, W. Kraiński, M. Sitarz, Toruń 2011, s. 167-178.

Miziński A., Pojęcie kościelnego aktu administracyjnego, w: Organizacja i funkcjonowanie administracji w Kościele, red. J. Krukowski, W. Kraiński, M. Sitarz, Toruń 2011, s. 109-142.

Miziński A., Rekurs do Najwyższego Trybunału Sygnatury Apostolskiej z tytułu nielegalności aktu administracyjnego, „TEKA Komisji Prawniczej PAN Oddział w Lublinie" 4 (2011), s. 102-117.

Paulus vi, Constitutio apostolica De Romana Curia Regimini Ecclesiae Universae, 15.08.1967, „Acta Apostolicae Sedis” 59 (1967), s. 885-928; tekst polski w: Ustrój hierarchiczny Kościoła, red. W. Kacprzyk, M. Sitarz, Lublin 2006, s. 166-196.

Przytuła F., Zasada legalności a funkcjonowanie administracji kościelnej, Lublin 1985. Rozkrut T., Ochrona sądowa praw wiernych - szczegółowe zagadnienia wybrane, w: 25-lecie promulgacji Kodeksu Prawa Kanonicznego. Obowiazywanie i stosowanie w Polsce, red. J. Krukowski, Z. Tracz, Łódź 2009, s. 107-120.

Sitarz M., Kompetencje kontrolne Stolicy Apostolskiej względem działalności legislacyjnej organów władzy w Kościele partykularnym, w: Finis legis Christus. Ksiegga pamiątkowa dedykowana Księdzu Profesorowi Wojciechowi Góralskiemu z okazji siedemdziesiątej rocznicy urodzin, red. J. Wroceński, J. Krajczyński, Warszawa 2009, s. 725-738.

Sitarz M., Zasada legalności w sprawowaniu władzy administracyjnej w Kościele, w: Organizacja i funkcjonowanie administracji w Kościele, red. J. Krukowski, W. Kraiński, M. Sitarz, Toruń 2011, s. 65-86.

Sobór Watykański II, Konstytucja dogmatyczna o Kościele Lumen gentium, w: Sobór Watykański II, Konstytucje, dekrety, deklaracje, Poznań 2002, s. 104-166.

\section{Streszczenie}

Sprawiedliwość administracyjna w Kościele to całokształt środków prawnych, dzięki którym wierni mogą domagać się od władzy administracyjnej Kościoła działania zgodnego z przepisami prawa i szeroko rozumianą sprawiedliwością. Jest ona odzwierciedleniem podstawowego prawa do obrony, które przysługuje wszystkim wiernym, a które wynika z ich godności i konkretnej pozycji w Kościele.

Poprzez zasadę legalności ustawodawca kościelny wskazuje, że kościelne organy władzy wykonawczej mają obowiązek wydawania decyzji oraz stanowienia 
konkretnych aktów administracyjnych z zachowaniem norm prawa kanonicznego, które należy rozumieć jako zespół norm usytułowanych w ustawach i innych aktach prawnych, odpowiednio usystematyzowanych, zarówno pochodzenia czysto ludzkiego, jak i Bożego.

W systemie kościelnego prawa administracyjnego wierni mają szeroki wachlarz środków prawnych, służących ochronie należnych im praw podmiotowych: od środków pojednawczych, których celem jest podjęcie działań zmierzających do uniknięcia sporu administracyjnego, po środki odwoławcze, umożliwiające dochodzenie własnych praw na sali sądowej czy forum administracyjnym.

\section{Słowa kluczowe}

sprawiedliwość administracyjna, Kościół, rekursy administracyjne, zasada legalności

\section{Summary}

\section{Administrative Appeals in the System of Administrative Justice in the Church}

Administrative justice in the Church is overall legislative measures thanks to which the faithful may request actions from the administrative authority of the Church in accordance with the law and in a broad sense of justice. It reflects the fundamental rights of defence that have all the faithful and which flows from their dignity and a specific position in the Church.

Through the principle of legality of the church legislature indicates that the Church executive authorities are responsible for issuing decisions and regulating specific administrative acts in accordance with standards of canon law that should be understood as set of rules situated in laws and other legal acts respectively classified both of a purely human and divine origin.

In the system of ecclesiastical administrative law the faithful have a wide range of legal means to protect the rights owed to them. By way of starting with reconciliation measures, aim of which is to take measures to avoid the administrative dispute, the forms which have their justification by the way of dispute, enabling investigation of one's own rights in court or administrative forum.

\section{Keywords}

administrative justice, the Church, administrative appeals, principle of legality 